Synthesis of Large Molecules". In Nature, all organized objects consist of large molecules. The great importance of the natural highly polymerized substances has led to the conclusion that very valuable mechanical and physiological behaviour is associated with these macro-molecules. Therefore the industries concerned with synthetic rubber, artificial silk and synthetic resins have worked out a number of synthetic high polymers, which are, in fact, of great use in making insulators, fibres and solid materials of high resistance and valuable properties. It appears that the kinetics of polymerization reactions is very complicated, but one can already distinguish three main processes which play an important role in every polymerization reaction. First a nucleus of high reactivity must be built. This can be done by a thermal collision of high energy, or photochemically, or by means of a catalytic agent. The production of these nuclei requires a high activation energy, and is therefore rather slow. The nuclei react quickly with the molecules of the monomeric substance and grow with rather high velocity stepwise to a chain. The activation energy of the growing reaction is low (about 5,000 cal./mol.) and therefore the probability of the growth is large. The chains would grow infinitely if there were not break-up reactions of different kinds. There is the possibility that the growing of the chains may be ended by lack of monomeric substance; it is possible that the decreasing steric factor of the association reaction may diminish the velocity of chain growth to a very low rate, and one must consider that different sidereactions may break up the chains suddenly. In the case of styrene, we have succeeded in distinguishing these three different stages and developing a reaction mechanism which seems to be in fair agreement with the experimental data.

\section{Recent Acquisitions at the Natural History Museum}

Among recent additions to the Zoological Department at the British Museum (Natural History) is a specimen of the pigmy scalytail of West Africa received from the Basle Museum. The Department has also acquired a large number of small mammals and birds from Yugoslavia collected by $\mathrm{Mr}$. V. Martino. This collection, comprising a number of new forms, is of considerable scientific importance and will help to fill one of the chief gaps in the study collections of mammals and birds. An important purchase for the Department of Entomology is the remainder of the Fruhstorfer collection of butterflies. 13,799 specimens, comprising the Lycænidæ and Hesperiidæ, were purchased by the Trustees in 1933, and a small section of the collection (the oriental Nymphalidæ) have in the interval been sold to the Paris Museum. The balance now acquired.consists of 48,677 specimens, of which about 3,000 are the actual specimens upon which the original descriptions of the species were based. The Mineral Department has been given by Mr. J. D. Hague a specimen of native gold in beautiful bright crystals, from the North Star mine, California. Mr. Felix F. Wilson has presented a small collection of gold which has been picked up from burns at Leadhills, in Lanarkshire, by the late Mr. Thomas Newbiggin, who was for many years engaged in mining there. A magni. ficent, clear blue, step-cut, flawless blue topaz, 614 carats in weight, from Brazil has been bought. Owing to the easy cleavage of this mineral, it is seldom that a coloured stone of this size is so free from flaws.

\section{Fourth International Grassland Congress}

ThE fourth International Grassland Congress is to be held in Great Britain on July 8-23 under the presidency of Prof. R. G. Stapledon. The paper. reading sessions will be held in Aberystwyth on July 14-18. Before and after these sessions, delegates will be shown the leading types of grassland in Great Britain, in a tour from Oxford to Aberystwyth and from Aberystwyth to Edinburgh. Fifteen plenary papers are to be presented to the Congress by delegates from Great Britain, Sweden, Germany, Italy, Fin. land, United States, Canada, Australia, New Zealand and South Africa. The remaining papers will be read to sectional meetings of the Congress, which will deal with the following aspects of the grassland problem : (1) grassland ecology, (2) seeds mixtures, (3) plant breeding and seed production, (4) fertilizers, (5) nutritive value and fodder conservation, and (6) pastures. Full details regarding plans for this Congress and a list of all papers to be presented are obtainable from the Joint Secretaries, Fourth International Grassland Congress, Aberystwyth. Particular attention is directed to the closing dates for receipt of applications (May 15 and June 19, according to the option selected).

\section{The Parliamentary Science Committee}

The latest addition to the constituent bodies of the Parliamentary Science Committee is the British Institute of Radiology. For some time past the Committee has been engaged in investigating how the Patent Office Library could be brought up to date in such a manner as to serve the interests and convenience of the public who make use of that Library. The British Science Guild undertook a similar inquiry some years ago, and the Parliamentary Science Committee made its report the starting point for the investigation. A report has been completed, and the Parliamentary Science Committee has been in communication with the Chartered Institute of Patent Agents. Dr. Leslie Burgin, M.P. (Parlia. mentary Secretary of the Board of Trade), has now consented to receive a deputation from the Parliamentary Science Committee on the subject on May 3. The deputation will be introduced by Sir Arnold Wilson, the chairman of the Committee, and it will include two or three members of parliament who are also members of the Committee.

\section{The Mellon Institute}

THE new building of the Mellon Institute, Pitts. burgh, will be dedicated on May 5-9. At the formal dedication of the building in the afternoon of May 6 
in Carnegie Music Hall, with Dr. Weidlein presiding, addresses will be given by three Nobel prizemen, namely, Dr. Irving Langmuir (chemistry), Dr. H. C. Urey (physical chemistry), and Dr. W. P. Murphy (medicine). Brief addresses will also be given by Andrew W. Mellon and Richard K. Mellon, representing the founders. A symposium on "Recent Progress in Science" will be held on May 7. Speakers will include Dr. G. O. Curme, jun., Dr. F. B. Jewett, Sir Frederick Banting and Dr. W. W. G. Maclachlan. The new building, which has taken six years to complete, is to be dedicated to science and humanity in honour of Andrew W. and Richard B. Mellon, founders of the institution, who in 1911 gave support to the research fellowship system advanced by the late Robert Kennedy Duncan by establishing a specific department at the University of Pittsburgh, and in 1913 placed the system on a permanent basis with the organization of Mellon Institute.

\section{Discharged Soldier Settlers in New Zealand}

According to the report of the New Zealand Department of Lands and Survey on Discharged Soldiers Settlement for the year ended March 31, 1936, a further twelve applications for land were received during the year, seven of which were granted, making a total of 4,093 allotments, covering $1,440,818$ acres in the twenty-one years the Act has been in force. A grand total of $1,452,829$ acres has been proclaimed for this purpose since the inception of the scheme. Loans authorized during the year numbered 719, involving an amount of $£ 66,517$. Reports from the District Commissioners of Crown Lands indicated that the soldier settlers, most of whom are engaged in dairy farming or sheep farming, have had a better year, although those engaged in orchards again had a poor season owing to inclement weather.

\section{Rockefeller Foundation China Programme}

The Chinese Mass Education Movement, the Colleges of Public Affairs and Natural Sciences at Yenching University and the Institute of Economics of Nankai University received aid from the Rockefeller Foundation during 1935. In the part of the China programme centring round Nanking in south China, support was extended to the national health administration; to the Commission on Medical Education, and to three institutes interested in agricultural development; to the University of Nanking for its departments of agricultural economics and science; the National Central University for work in animal husbandry and veterinary preventive medicine; and the National Agricultural Research Bureau for insect control work. Local fellowships in China granted by the Foundation numbered 140 .

\section{Maintenance of Isothermal Chambers}

$A x$ the Institution of Electrical Engineers, Savoy Place, W.C.2, on May 5 at 6 p.m., Mr. L. B. Turner, a well-known radio-physicist of Cambridge, will present a paper describing a method he has devised of keeping a mains-operated isothermal chamber at a temperature constant to one thousandth of a degree centigrade. Although designed for a specific engineering application, it is likely to prove of interest to biological research workers and they are invited to attend the meeting. Biologists are specially interested in the maintenance of extremely constant tempera. tures ; for minute changes of heat production in living tissue, detected by thermocouple, have been used as an index of vital process; and these changes can be measured only when the body under examination is protected from temperature fluctuation imposed from outside.

\section{Conference on Large High Tension Systems}

THE International Conference on Large Electric High Tension Systems will be held in Paris on June 24-July 3. It was established in 1921 with the sole object of studying the problems connected with the high-tension transmission of power. The organization and interpretation facilities will enable anyone speaking English to profit fully by the work of the Congress. An attractive programme of visits and excursions has been arranged and special terms are offered by many of the hotels and railways to registered members of the Congress. Further details may be obtained from the Secretariat, Avenue Marceau, 54, Paris, or the Secretary, Institution of Electrical Engineers, Savoy Place, London, W.C.2.

\section{Travelling Fellowships in Medicine}

The Medical Research Council invites applications for six Rockefeller medical fellowships for the academic year 1937-38. They are intended for British graduates who have had some training in research work in clinical medicine or surgery, or in some other branch of medical science, and who are likely to profit by a period of work at a centre in the United States or elsewhere abroad, before taking up positions for higher teaching or research in the United Kingdom. The Council also invites applications for four Dorothy Temple Cross research fellowships in tuberculosis. The object of these fellowships is to give special opportunities for study or research to suitably qualified British subjects of either sex "intending to devote themselves to the advancement by teaching or research of curative or preventive treatment of tuberculosis in all or any of its forms". Further information and forms of application, returnable not later than June 1, are obtainable from the Secretary, Medical Research Council, 38 Old Queen Street, Westminster, S.W.1.

\section{Royal Aeronautical Society Awards}

ON April 26, Mr. H. E. Wimperis delivered his presidential address to the Royal Aeronautical Society on the subject of the natural limits to human flight, and the following medals and awards were presented : Society's Gold Medal to the late Señor J. de la Cierva, for his work on the development of the autogiro; Society's Silver Medal to F. W. Meredith, for his work on the automatic pilot; Society's Silver Medal to P. A. Cooke, for his work on the automatic pilot; British Gold Medal for Aeronautics to A. Gouge, for his achievement in the development of 